\title{
The extent of South African authored articles in predatory journals
}

\section{Johann Mouton ${ }^{1,2}$}

AUTHORS:

Astrid Valentine $e^{1,2}$

\section{AFFILIATIONS:}

${ }^{1}$ Centre for Research on Evaluation, Science and Technology (CREST), Stellenbosch University, Stellenbosch, South Africa

${ }^{2} \mathrm{DST} / \mathrm{NRF}$ Centre of Excellence in Scientometrics and Science, Technology and Innovation Policy, Stellenbosch University, Stellenbosch, South Africa

\section{CORRESPONDENCE TO: Johann Mouton}

\section{EMAIL:}

jm6@sun.ac.za

\section{DATES:}

Received: 11 Jan. 2017

Revised: 10 Apr. 2017

Accepted: 12 Apr. 2017

\section{KEYWORDS:}

predatory publishing; scholarly publishing; South Africa; open access journals; DHET funding framework

\section{HOW TO CITE:}

Mouton J, Valentine A. The extent of South African authored articles in predatory journals. S Afr J Sci. 2017;113(7/8), Art. \#2017-0010, 9 pages. http://dx.doi.org/10.17159/ sajs. $2017 / 20170010$

\section{ARTICLE INCLUDES: \\ $\times$ Supplementary material \\ $\times$ Data set}

FUNDING:

None
We present a first estimate of the extent of predatory publishing amongst South African academics. This estimate is based on an analysis of all South African authored papers that qualified for subsidy over the period 2005 to 2014. The analysis shows that 4246 South African papers were published in 48 journals which we re-classified (refining Beall's classification) as either being probably or possibly predatory. A breakdown of these papers by year shows that the greatest increase in predatory publishing has occurred since 2011. Results are also presented of the distribution of these papers by individual university and scientific field. We conclude with some suggestions about predatory publishing and its pervasive consequence for our trust in science and how this should be addressed by the major stakeholders in the South African higher education system.

\section{Significance:}

- This study is the first to analyse the extent of predatory publishing in South Africa.

\section{Introduction}

The aim of this paper is to report on a study undertaken by CREST (Centre for Research on Evaluation, Science and Technology) to estimate the extent of predatory publishing amongst South African academics. A few South African studies and reports have appeared in recent years which have suggested that predatory publishing is not only present but is in fact becoming more pervasive - at least in some disciplines. ${ }^{1,2}$ However, no study has been done that presents a systematic assessment of how many articles, authored by South African academics, have been published in predatory journals.

There has been a surge of interest in predatory publishing and its effects in recent years, with two kinds of 'studies' emerging. The first are scholarly publications that analyse the nature and dynamics of predatory publishing. Included in this category are studies by Bohannon ${ }^{3}$, Bowman ${ }^{4}$, Djuric ${ }^{5}$, Gasparyan et al. ${ }^{6}$, Jalalian and Mahboobi ${ }^{7}$, Kozak et al. ${ }^{8}$, Nelson and Huffman ${ }^{9}$, Shen $^{10}$, Sipka ${ }^{11}$, Svab and Makivic ${ }^{12}$, Tin et al. ${ }^{13}$ and Xia et al..$^{14,15}$ Arguably the most comprehensive of these is a report in 2012 by Truth ${ }^{16}$ entitled 'Pay big to publish fast: Academic journal rackets'.

The second category of articles on predatory publishing is editorials and commentaries in journals which are more polemical and critical in nature. Articles of this kind are typically written by prominent scholars and editors of journals and point to the increasing prevalence of predatory publishing and its far-reaching consequences for scholarly publishing and specifically the peer-review system in science. Examples of the latter are Bartholomew's editorial in the Journal of the Royal Society of Medicine ${ }^{17}$ and Moher and Srivastava's Correspondence note in BMC Medicine ${ }^{18}$.

\section{Predatory publishing: A threat to peer review?}

Peer review in science has been around for more than two centuries. Most often authors date the advent of what we now call editorial peer review to the 1752 Royal Society of London's development of a 'Committee on Papers' to oversee the review of text for publication in the journal Philosophical Transactions. Others insist the Royal Society of Edinburgh had a similar system in place as early as 1731. The shortcomings of peer review have been well documented. ${ }^{19}$ These include bias in the review process (institutional bias, gender bias), conflicts of interest between reviewers and authors, rejection of very innovative (radical) research, and so on. However, none of this evidence suggests the wholescale rejection of the peer-review mechanism. But a number of recent events have re-opened debates on peer review:

- The continuing growth in the demand for publishing journal articles (role of new big players such as India and China).

- Increased competition to publish (the effect of continuing globalisation and the role of ranking systems).

- The new opportunities to publish through the availability of online journals (and specifically mega journals such as PLOS).

The enormous pressure to publish and publish fast — preferably in the very best journals - influences both authors and editors. This pressure exists almost everywhere but is particularly intense in Asia (China and India). It is therefore no surprise that the most inventive ways to game the peer-review system to get manuscripts published have come from China and India. ${ }^{20}$ The companies that provide fake peer reviews come from countries in Southeast Asia, and most of the authors involved in these cases come from the same areas. But it would be a mistake to look at this as a Chinese or Asian problem. This situation is no less true in South Africa where we have for some time now become aware (even if anecdotally) of the pervasive, and in some cases also perverse, effects of the Department of Higher Education and Training (DHET) funding system. 
Although there is now widespread awareness, and presumably also knowledge, of what predatory publishing is, it is still important to have a clear understanding of what is meant by predatory publishing and how it is defined.

\section{What is predatory publishing?}

The term 'predatory publishing' is usually attributed to Jeffrey Beall a librarian at the University of Colorado in Denver (USA). Beall, who was until recently regarded as the unofficial 'watchdog' of predatory publishing, administered a website entitled 'Scholarly Open Access: Critical analysis of scholarly open-access publishing'. This website was rather abruptly closed on 17 January 2017 . It is only very recently that Beall broke his silence on the closure of the website. ${ }^{21}$

In his first major publication on the topic published in Nature in 2012, Beall provided a first description of what is meant by predatory publishing22:

Then came predatory publishers, which publish counterfeit journals to exploit the open-access model in which the author pays. These predatory publishers are dishonest and lack transparency. They aim to dupe researchers, especially those inexperienced in scholarly communication. They set up websites that closely resemble those of legitimate online publishers, and publish journals of questionable and downright low quality. Many purport to be headquartered in the United States, United Kingdom, Canada or Australia but really hail from Pakistan, India or Nigeria. Some predatory publishers spam researchers, soliciting manuscripts but failing to mention the required author fee.

Beall uses the term 'predatory' to refer to journals that 'prey' on (often unsuspecting and often young) scholars to submit their manuscripts for the sole purpose of making money from these scholars. In this process, normal good editorial and review processes are violated or suspended.
Because these journals typically do not undertake any peer review (or very superficial peer review), they are thus able to accept large numbers of manuscripts within very short turnaround times and hence make their money through high volume. Beall's point is that predatory journals and publishers are in the business of defrauding scientists and scholars.

Even though Beall's listing is relatively new, there have already been a number of contestations around whether his classification of specific journals are in fact correct. He has also been criticised by a small number of scholars for his methodology and subsequent classification of predatory journals. ${ }^{23,24}$ Many of these critics make the obvious point that one needs to distinguish between journals that do not adhere to good and ethical practices of publishing (including editorial and review practices) and journals (and publishers) that deliberately intend to defraud the scholarly publishing process for the purpose of making money. As part of the latter process, such journals (for which we also use the term 'predatory') typically engage in a range of practices (summarised below) that have the same characteristics as poor and 'sloppy' journals (the first category), but to a greater extent. As we argue below, the intention to deceive and defraud by these predatory journals is very evident in the use of fake journal metrics, excessive acceptance rates and extremely short turnaround times. We also argue that a very credible indicator of what constitutes predatory practices (as opposed to simply poor publishing practices) is evidenced by the exponential growth - especially in recent years - of the number of papers accepted and published by these journals.

In our study we did not take Beall's classification at face value but undertook a more in-depth assessment of the journals - tagged by him as predatory - in which South African authored papers have been published. We summarise what we mean when scholars refer to predatory journals and or predatory publishing in Table 1, where we compare the criteria or rules that we believe apply to standard (and ethical) scholarly publishing practices and those that are found in predatory publishing.

In the remainder of the paper we report on the results and consequences of our analysis of predatory publishing in South Africa.

Table 1: Comparing the characteristics of good practice in scholarly publishing with those of predatory publishing

\begin{tabular}{|c|c|c|}
\hline Category & Standard publishing practice & Predatory publishing \\
\hline Business model & Legitimate scholarly journals do not exist solely for profit & $\begin{array}{l}\text { Predatory journals are open-access journals that exist for the sole } \\
\text { purpose of making a profit }\end{array}$ \\
\hline Origin of papers & Authors usually submit manuscripts to journals of their own accord & $\begin{array}{l}\text { Predatory journals typically solicit manuscripts by spamming } \\
\text { researchers (especially using their Yahoo and Gmail accounts) }\end{array}$ \\
\hline Journal titles & $\begin{array}{l}\text { Legitimate journals usually have field- and discipline-appropriate } \\
\text { titles }\end{array}$ & $\begin{array}{l}\text { Predatory journals often have bizarrely broad titles (e.g. the Global } \\
\text { Journal of Advanced Research) or titles with disjointed scopes (e.g. } \\
\text { the Journal of Economics and Engineering) }\end{array}$ \\
\hline Time to publication & $\begin{array}{l}\text { Publication lag time is often correlated with the status of the } \\
\text { journal (with the best journals taking more time to get to production } \\
\text { because of high demand) }\end{array}$ & $\begin{array}{l}\text { These journals boast extremely rapid (and unrealistic) response } \\
\text { (review) and publication times. They often also publish extremely } \\
\text { high numbers of papers per year. This is arguably one of the best } \\
\text { indicators of whether a journal is predatory or not as it speaks to the } \\
\text { capacity of any editor to handle literally hundreds of submissions } \\
\text { per year through proper peer review. }\end{array}$ \\
\hline Journal metrics & $\begin{array}{l}\text { Journals indexed in Web of Science and Elsevier Scopus have well- } \\
\text { defined and transparent impact factor values }\end{array}$ & $\begin{array}{l}\text { These journals boast extraordinary and often fake journal impact } \\
\text { factors as well as false claims about where the journal is indexed }\end{array}$ \\
\hline $\begin{array}{l}\text { Peer review (stature of } \\
\text { editorial board) }\end{array}$ & $\begin{array}{l}\text { Legitimate journals have editorial procedures and editorial boards } \\
\text { that properly oversee the process of peer review }\end{array}$ & $\begin{array}{l}\text { Predatory journals very often have fake editorial boards or - at best - } \\
\text { editorial boards that consist of a small number of individuals from the } \\
\text { same organisation or country. They often enlist members of editorial } \\
\text { boards who are not experts in the field. They also often include } \\
\text { scholars on an editorial board without their knowledge or permission. }\end{array}$ \\
\hline Contact information & $\begin{array}{l}\text { Legitimate journals provide accurate and appropriate contact } \\
\text { information about their journal and editorial board }\end{array}$ & $\begin{array}{l}\text { Predatory journals often list false or insufficient contact information, } \\
\text { including contact information that does not clearly state the } \\
\text { headquarters location or misrepresents the headquarters location } \\
\text { (e.g. through the use of addresses that are actually mail drops) }\end{array}$ \\
\hline
\end{tabular}




\section{Methodology}

The source for our analysis is CREST's proprietary database - SA Knowledgebase - that contains a list of all South African publications (articles, books, book chapters and conference proceedings) that have been submitted for funding to the DHET for the period 2005 to 2014. This database contains information about 116373 papers authored or coauthored by South African academics in 8060 journals that are recognised by DHET for subsidy purposes. The database contains information about the authors, their institutional affiliations, journal title, publication year, the list in which the journal was indexed (Web of Science, IBSS or DHETaccredited journals) and the subject category of scientific field/ discipline (linked to the journal). In order to conduct the analysis for this paper, we consulted Beall's list on predatory journals and predatory publishers and tagged journals in our database if belonging to either.

It is important to emphasise that Beall maintained two lists: a list of standalone predatory journal titles (1220 titles at the time of writing this paper) and a list of predatory publishers. Since the closure of Beall's website, these lists have now been archived elsewhere. ${ }^{25}$ The former list is simply a list of individual journals which, according to Beall, are predatory journals. For some of these he provided additional information in support of his judgement. The latter - a list of journal (and sometimes also book and proceedings) publishers - is much more comprehensive but at the same time arguably less reliable. In this instance, Beall usually argued that a particular publishing house (such as Academic Journals or OMICS) has a demonstrated history of publishing questionable journal titles. Because of this history, all journal titles listed by the publisher are hence regarded as being predatory journals. We estimate that there were just over 900 active publishers on Beall's list at the time of writing this paper. If one sums the number of journals listed under these publishers, the number comes to a staggering $23400+$ titles. But as we argue below, it is not always clear that every one of these journal titles should be 'tagged' as predatory.

If we take Beall's list as our point of departure, we have 57 journal titles in which 4245 South African authored papers have appeared between 2005 and 2014. We assessed each of these 57 titles and subsequently assigned each of the titles to four categories:

1. Not predatory: In these cases we believe that Beall is simply wrong in his classification of the journal.

2. Strong evidence for predatory: In these cases we concur with Beall's classification.

3. Weak evidence for predatory: In these cases we found some evidence that the journal might be a predatory journal, but do not think the evidence is strong enough to make a definitive judgement.

4. Insufficient evidence: In these cases we simply could not find any pertinent evidence to make a judgement either way. If one assumes that the 'burden of proof' in this case is on the 'assessor', these journals should probably be tagged as 'not predatory' - at least for the time being.

Before presenting further detailed results, we elaborate on our categorisation.

\section{Not predatory}

First, there are clear-cut cases in which Beall has incorrectly 'tagged' a journal as being 'predatory'. Arguably the best case is Beall's inclusion of the International Journal of Electrochemical Science as a predatory journal. When asked in January 2014 why he classified this journal as predatory, Beall responded that the journal had lost its impact factor in Thomson Reuters Journal Citation Reports in $2012 .{ }^{26}$ From this exchange it seems that one of the reasons for including the journal on his list was because Beall discovered that it was 'suppressed by Thomson Reuters in 2012'. However, the current information on the Journal Citation Reports web page reports citation data and specifically journal ranking data for this journal every year since 2013. It is simply the case that Thomson Reuters decided not to report on the journal citation profile in 2012. However, it is in fact standard bibliometric practice by Thomson Reuter's Web of Science to omit citation profile information when a particular journal does not record a minimum number of citations during a particular year. It certainly should not be interpreted as some fraudulent practice on the part of the journal itself (and Beall should have known this).

We also do not believe that the Journal of Animal and Plant Sciences, which has been published by the Biosciences Unit of F.a.C.T Ltd, Nairobi (Kenya) since 2002, is predatory. There is another journal with the same name which has been published in Pakistan since 1991, but we do not see any evidence that this is a case of hijacking. ${ }^{27}$ The Pakistani journal does not list the name of its editor (which is taken as evidence by Beall of a predatory journal), but for the remainder we could not find evidence of it being predatory.

Similarly, we could not find any evidence that Mathematical and Computational Applications is a predatory journal. On the contrary, it seems to be a well-established journal in a number of European countries and is published by the Multidisciplinary Digital Publishing Institute - an academic open-access publisher with headquarters in Basel, Switzerland.

\section{Distinction between weak and strong evidence for predatory}

Based on our inspection of the remaining 47 titles, we argue that it is not always a clear-cut and unambiguous decision whether a journal is in fact a predatory journal. More investigation and a more precise 'scoring' or 'assessment' system whereby suspected predatory journals are subjected to rigorous scrutiny is needed. One way to do this would be to take the current criteria for identifying predatory journals (Table 1) and develop a set of operational rules according to which suspected journals could be assessed. In this study, we used three sources of evidence: (1) Beall's blogs on specific journals; (2) scholarly journals that refer to specific journals or publishers; and (3) our own case-by-case inspection.

As to the first source of evidence, Beall often made specific blog entries in which he discussed why he had categorised a specific journal as predatory. Where we could find such blog entries (there were not entries for all the predatory titles), we looked at the evidence and if we concurred with his assessment, we classified such a journal as predatory with strong evidence. We believe that these entries constitute 'strong' evidence because most of these entries are first-hand reports from authors who have been the 'victims' of these journals. They can rightly be accepted as first-hand qualitative evidence of instances of fraudulent practices. One example refers to a journal - the African Journal of Business Management - in which South African authors have published quite prodigiously. Beall had an extensive blog on this journal. ${ }^{24} \mathrm{He}$ described a scam involving the review process as follows:

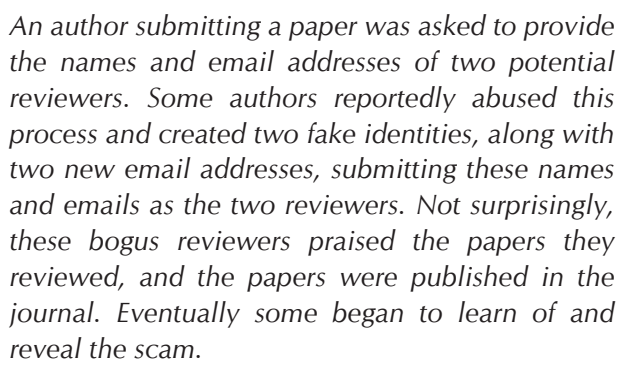

As to the second type of evidence, there are a number of scholarly studies in which specific 'case' investigations have been made of specific journals. ${ }^{13,16}$ Again, our approach was to look at these studies and then make a judgement on whether the evidence supports the classification of a specific journal or publisher as being predatory.

The final source of evidence was our own inspection of each of the journal titles. And in this case, we looked for the following 'indicators' that the journal is predatory:

1. Incompleteness or inaccuracy of information on the members of the editorial board

2. Fake claims about indexing of the journal or journal impact factor

3. Growth in the number of papers accepted for publication 
It is important to emphasise that we would typically attempt to find evidence of at least two of the indicators referred to above. We accept that the first indicator, if taken on its own, would at best point to poor or sloppy editorial practices. We, therefore, did not take the first indicator (incomplete or inaccurate editorial board information) on its own as constituting sufficient evidence to make a judgement about the journal's predatory 'status'. The second indicator - making fake claims - was taken to be a much stronger indicator. We believe making false claims about journal metrics is a deliberate act on the part of the editor or publisher to deceive and should not be dismissed as mere ignorance on their part. We give some examples of how these criteria were applied.

Information provided by the African Journal of Pharmacy and Pharmacology on their editors is suspect to say the least. The information on the editor, Himanshu K. Gupta, does not correspond to the link to his name. Himanshu K. Gupta is listed as affiliated to the Department of Pharmacy Practice at the University of Toledo. But when one follows the link to his name, it takes one to the Ministry of Defence Government of India, Department of Nuclear Medicine in New Delhi. Another editor listed is Shreesh Kumar 0jha. She is listed as being with the University of Arizona, but the link to her name takes you to the United Arab Emirates University, Department of Pharmacology and Therapeutics, Al Ain, United Arab Emirates. We could not find her name on the staff list of the University of Arizona.

Three of the journals represented in our list (all from Kamla-Raj Publishers) - the International Journal of Education Sciences, the Journal of Human Ecology and the Journal of Social Sciences - are examples of blatant false claims in regard to the members of their editorial boards. For example, Prof. Kenneth Kennedy who is listed as an editorial member of the Journal of Human Ecology died in 2014 and Prof. Richard Brown who is listed as an editorial member of the Journal of Social Sciences died in 2003. Another telltale sign of predatory publishing is the overlap in the names of editorial board members across various predatory journals. Dr Bryan Hiebert who is listed as an editorial member of the International Journal of Education Sciences is also listed as an editorial member of the International Scholars Journal - also identified by Beall as most likely a predatory journal. The same applies to three Nigerian academics who also appear on the editorial boards of both journals: Dr. Alfred A. Adegoke, Dr Godson C. Igborgbor and Dr Oyaziwo Aluede.

A very common example of false claims relates to claims that predatory journals make about indexing and journal impact factors. An example from our list is the Journal of Natural Products (India). This journal is published in India (at http://journalofnaturalproducts.com/) and is not to be confused with a legitimate journal with the same title which is produced by ACS or the Natural Products Journal which is published by the Bentham Institute. On their website, the predatory journal cites two impact factor values for 2013: 1.265 , purportedly produced by a company called the Universal Impact Factor and another value for the same year produced by another company called Global Impact Factor-Institute for Information Resources. Neither of these companies exists and so are not in the business of producing legitimate journal impact factors.

Predatory journals engage in various strategies to solicit business (most often by spamming potential authors) and publish as many papers as they can. As a result, one often sees that predatory journals record exponential increases in the number of publications over very short time frames, thereby raising the question about their capacity to undertake rigorous and appropriate peer review. The African Journal of Business Management is a case in point. Truth ${ }^{16}$ records how the journal has expanded exponentially between 2007 and 2011:

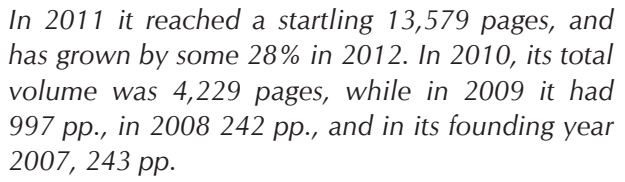

Thomson Reuters was asked in 2010 to review the African Journal of Business Management and finally removed the journal from its list in February 2012, some 18 months after serious questions regarding the journal's practices were submitted to the knowledge firm.
Other journals by the same publisher - Academic Journals - which is based in Lagos, Nigeria exhibit similar characteristics, leading us to categorise them as 'probably predatory'. Two examples are the African Journal of Agricultural Research (242 papers) and the African Journal of Biotechnology (452 papers). The African Journal of Agricultural Research shows on its website that it has published 5242 articles since 2006. This number translates into an average of 476 articles per year. The same applies to the African Journal of Biotechnology which indicates on its website that it has published 11688 articles since it was established in 2002. This translates into an average of 780 papers per year! Both these journals currently charge between USD550 and USD650 per submitted article. Even if we work on a lower average of USD500 per submission, it means that these two journals have generated USD2.6 million and USD5.8 million in revenue, respectively, for their owners. Academic Journals currently has 111 journals in its stable.

As we have argued that the third indicator is a very 'persuasive' indicator of probable predatory practices, we present information in Table 2 that shows the huge increases in recent years in journals in which South African academics have published (we have included only those journals that we have classified as 'probable' predatory journals in which at least 100 papers appeared over the past 5 years).

Table 2: 'Predatory' journals with South African authored papers: 2005-2014

\begin{tabular}{|c|c|c|c|c|c|c|}
\hline Journal & 2010 & 2011 & 2012 & 2013 & 2014 & Total \\
\hline Journal of Social Sciences & 17 & 73 & 130 & 111 & 145 & 476 \\
\hline $\begin{array}{l}\text { African Journal of Business } \\
\text { Management }\end{array}$ & 53 & 120 & 214 & 26 & & 413 \\
\hline Journal of Human Ecology & 3 & 31 & 54 & 87 & 104 & 279 \\
\hline Corporate Ownership and Control & 24 & 42 & 46 & 62 & 66 & 240 \\
\hline $\begin{array}{l}\text { International Business and } \\
\text { Economics Research Journal }\end{array}$ & 13 & 21 & 39 & 80 & 77 & 230 \\
\hline $\begin{array}{l}\text { International Journal of } \\
\text { Educational Sciences }\end{array}$ & & & 17 & 40 & 130 & 187 \\
\hline $\begin{array}{l}\text { Anthropologist: International } \\
\text { Journal of Contemporary and } \\
\text { Applied Studies of Man }\end{array}$ & 1 & 17 & 49 & 33 & 50 & 150 \\
\hline Total & 111 & 304 & 549 & 439 & 572 & \\
\hline
\end{tabular}

In all the cases there is evidence of a sudden spike in the number of South African authored papers: often between 2010 and 2011 but also between 2011 and 2012. The only case where this trend is reversed is the African Journal of Business Management with no publications in 2014. This can probably ascribed to the fact that this journal was removed from Thomson Reuters in 2012; it was 'exposed' as a predatory journal by Thomas ${ }^{2}$ in 2015 .

\section{Results}

Using this fourfold classification allowed us to estimate the overall extent of predatory publishing in South Africa. For this estimate we exclude the 339 papers in the 10 journals that we have classified as being either 'not predatory' or for which we have 'insufficient evidence' to make a judgement. This leaves a total number of 3906 papers which constitute $3.4 \%$ of the total article production by South African authors over the past 10 years. The disaggregation by evidence categories is as follows: 2891 papers (or 2.5\%) appeared in journals which we classified as probably predatory (strong supporting evidence) and 1015 (or 0.09\%) appeared in journals which we classified as possibly predatory (weak supporting evidence). Our resultant classification of the journals is summarised in Table 3. 
Table 3: Classification of 'predatory' papers by journal (2005-2014)

\begin{tabular}{|c|c|c|c|c|c|c|}
\hline Journal & $\begin{array}{l}\text { Listed in } \\
\text { DOAJ }\end{array}$ & $\begin{array}{c}\text { Not } \\
\text { predatory }\end{array}$ & $\begin{array}{l}\text { Insufficient } \\
\text { evidence }\end{array}$ & $\begin{array}{l}\text { Possibly } \\
\text { predatory } \\
\text { - weak } \\
\text { evidence }\end{array}$ & $\begin{array}{l}\text { Probably } \\
\text { predatory } \\
\text { - strong } \\
\text { evidence }\end{array}$ & $\begin{array}{c}\text { Number of } \\
\text { papers }\end{array}$ \\
\hline Actual Problems of Economics & No & 9 & & & & 9 \\
\hline African Journal of Agricultural Research & No & & & 251 & & 251 \\
\hline African Journal of Biotechnology & No & & & 472 & & 472 \\
\hline African Journal of Business Management & No & & & & 451 & 451 \\
\hline African Journal of Food Science & No & & & 2 & & 2 \\
\hline African Journal of Microbiology Research & No & & & 105 & & 105 \\
\hline African Journal of Pharmacy and Pharmacology & No & & & 61 & & 61 \\
\hline Aging-US & No & & & 1 & & 1 \\
\hline American International Journal of Contemporary Research & No & & & & 2 & 2 \\
\hline Anthropologist: International Journal of Contemporary and Applied Studies of Man & No & & & & 180 & 180 \\
\hline Archives Des Sciences Journal & No & & & & 15 & 15 \\
\hline Asian Journal of Chemistry & No & & & & 33 & 33 \\
\hline Banks and Bank Systems & No & & 21 & & & 21 \\
\hline Canadian Journal of Pure and Applied Sciences & Yes & & & & 1 & 1 \\
\hline Cellular and Molecular Biology & No & & & & 2 & 2 \\
\hline Corporate Board: Role, Duties and Composition & No & & & & 10 & 10 \\
\hline Corporate Ownership and Control & No & & & & 270 & 270 \\
\hline Environmental Economics & No & & 30 & & & 30 \\
\hline European Journal of Science and Theology & No & & & 3 & & 3 \\
\hline European Journal of Sustainable Development & Yes & & & 1 & & 1 \\
\hline European Scientific Journal & No & & & 3 & & 3 \\
\hline International Business and Economics Research Journal & Yes & & & & 241 & 241 \\
\hline International Journal of Advanced Computer Technology & No & & & 1 & & 1 \\
\hline International Journal of Computer Applications & No & & & 2 & & 2 \\
\hline International Journal of Educational Sciences & No & & & & 191 & 191 \\
\hline International Journal of Electrochemical Science & No & 232 & & & & 232 \\
\hline International Journal of Engineering and Applied Sciences & Yes & & & & 1 & 1 \\
\hline International Journal of Sustainable Development & No & & & & 14 & 14 \\
\hline Investment Management and Financial Innovations & No & & 9 & & & 9 \\
\hline Journal of Animal and Plant Sciences (Nairobi) & Yes & 12 & & & & 12 \\
\hline Journal of Applied Business Research & No & & & & 72 & 72 \\
\hline Journal of Communication (Delhi) & No & & & & 20 & 20 \\
\hline Journal of Economics (Delhi) & No & & & & 25 & 25 \\
\hline Journal of Economics and Behavioral Studies & No & & & 111 & & 111 \\
\hline Journal of Environmental Biology & No & & & 1 & & 1 \\
\hline Journal of Governance and Regulation & No & & & & 34 & 34 \\
\hline Journal of Human Ecology & No & & & & 289 & 289 \\
\hline
\end{tabular}




\begin{tabular}{|c|c|c|c|c|c|c|}
\hline Journal & $\begin{array}{l}\text { Listed in } \\
\text { DOAJ }\end{array}$ & $\begin{array}{c}\text { Not } \\
\text { predatory }\end{array}$ & $\begin{array}{l}\text { Insufficient } \\
\text { evidence }\end{array}$ & $\begin{array}{l}\text { Possibly } \\
\text { predatory } \\
\text { - weak } \\
\text { evidence }\end{array}$ & $\begin{array}{l}\text { Probably } \\
\text { predatory } \\
\text { - strong } \\
\text { evidence }\end{array}$ & $\begin{array}{c}\text { Number of } \\
\text { papers }\end{array}$ \\
\hline Journal of Industrial and Intelligent Information & No & & & 1 & & 1 \\
\hline Journal of Information Management & No & & 1 & & & 1 \\
\hline Journal of Media and Communication Studies & No & & 1 & & & 1 \\
\hline Journal of Medicinal Plants Research & No & & & & 98 & 98 \\
\hline Journal of Natural Products (India) & No & & & & 2 & 2 \\
\hline Journal of Physical Therapy Science & No & & & & 1 & 1 \\
\hline Journal of Psychology (Delhi) & No & & & & 12 & 12 \\
\hline Journal of Social Sciences & No & & & & 502 & 502 \\
\hline Journal of Sociology and Social Anthropology & No & & & & 68 & 68 \\
\hline Mathematical and Computational Applications & No & 21 & & & & 21 \\
\hline Mediterranean Journal of Social Sciences & No & & & & 72 & 72 \\
\hline Oncotarget & No & & & & 2 & 2 \\
\hline Problems and Perspectives in Management & No & & & & 68 & 68 \\
\hline Risk Governance and Control: Financial Markets and Institutions & No & & & & 42 & 42 \\
\hline Romanian Biotechnological Letters & No & & & & 1 & 1 \\
\hline Scientific Research and Essays & No & & & & 73 & 73 \\
\hline Studies of Tribes and Tribals & No & & & & 66 & 66 \\
\hline Studies on Ethno-Medicine & No & & & & 32 & 32 \\
\hline Technics Technologies Education Management & No & & & & 1 & 1 \\
\hline Turkish Online Journal of Educational Technology & No & & 3 & & & 3 \\
\hline Total & & 274 & 65 & 1015 & 2891 & 4245 \\
\hline
\end{tabular}

DOAJ, Directory of Open Access Journals

A cursory inspection of data presented in Figure 1 shows that the biggest increase has occurred in more recent years - especially since 2011. This is specifically true for article output in those journals that we have classified as being probably predatory.



Source: SA Knowledgebase, CREST

Figure 1: Increase in number of papers published by South African authors in predatory journals (2005-2014).
In the remainder of the paper we present further analyses of these results by university and subject category.

\section{The spread of predatory publishing by university}

Is predatory publishing in South African higher education confined to certain universities only? To address this question we disaggregated the number of papers by university. The results (Table 4) show that academics at all South African universities are engaging in this practice. But is predatory publishing more prevalent at some universities than others? In order to achieve a comparison across universities that differ in size (amongst other things) we decided to normalise the number of articles in predatory journals by the total article production of universities for this period. The results reveal quite large differences.

If we focus on the first two columns of Table 4 (strong evidence category), small proportions of papers (less than the mean of $2.5 \%$ ) were produced at the major research universities (the Universities of Cape Town, Stellenbosch, Pretoria, the Witwatersrand, Rhodes, KwaZulu-Natal, Free State and Western Cape) and one comprehensive university - Nelson Mandela University. At the other end of the spectrum we find that relatively large proportions (more than 10\%) of all papers produced over the past 10 years at Walter Sisulu University (WSU), Mangosuthu University of Technology (MUT), University of Fort Hare (UFH), University of Venda (UNIVEN), Durban University of Technology 
(DUT), Central University of Technology, Cape Peninsula University of Technology (CPUT), University of Limpopo (UL), University of Zululand, University of Johannesburg and Vaal University of Technology appeared in predatory journals. The pattern of predatory publishing in the category of 'possibly predatory journals' (weak evidence) is mostly similar with UFH, MUT, WSU, DUT, CPUT, UNIVEN and UL recording proportions of papers significantly above the national average.

\section{Predatory publishing by scientific field}

Our final analysis focused on the subject categories or scientific fields in which these papers were published. Using the link between journal title and subject field (as in the Thomson Reuters Web of Science database), each predatory journal was linked to a single subject category or scientific field. Although the assignment of journals to a single subject category is not always straightforward (even though we have utilised a category entitled 'Multidisciplinary science'), we believe that the general picture that emerged from this analysis presents a reasonably accurate picture of the spread of papers by subject category. We confined this analysis to journals classified as 'probably predatory'.

The distribution by field for papers published in the journals that we have classified as 'probably predatory' (strong evidence) shows that articles in the social sciences and humanities and the economic and management sciences dominate (Figure 2). This result is consistent with our disaggregation by university and why predatory publishing at some of the top research universities with large medical and natural sciences faculties is less common. Of course, the bigger question is why predatory publishing in South Africa is seemingly more prevalent in the broad field of the human sciences rather than in other fields.

Table 4: Classification of 'predatory' papers by South African university (2005-2014)

\begin{tabular}{|c|c|c|c|c|c|c|c|}
\hline University & $\begin{array}{c}\text { Predatory - } \\
\text { strong evidence }\end{array}$ & $\begin{array}{c}\text { Share of total } \\
\text { papers }\end{array}$ & $\begin{array}{c}\text { Predatory - weak } \\
\text { evidence }\end{array}$ & $\begin{array}{c}\text { Share of total } \\
\text { papers }\end{array}$ & Total 'predatory' & $\begin{array}{c}\text { Share of total } \\
\text { papers }\end{array}$ & $\begin{array}{c}\text { Total number of } \\
\text { papers }\end{array}$ \\
\hline CPUT & 107 & $7.9 \%$ & 80 & $5.9 \%$ & 187 & $13.8 \%$ & 1358 \\
\hline CUT & 71 & $13.4 \%$ & 11 & $2.1 \%$ & 82 & $15.5 \%$ & 528 \\
\hline DUT & 86 & $10.5 \%$ & 51 & $6.2 \%$ & 137 & $16.7 \%$ & 819 \\
\hline MUT & 22 & $16.3 \%$ & 13 & $9.6 \%$ & 35 & $25.9 \%$ & 135 \\
\hline NMMU & 41 & $1.8 \%$ & 8 & $0.4 \%$ & 49 & $2.2 \%$ & 2268 \\
\hline NWU & 357 & $4.7 \%$ & 51 & $0.7 \%$ & 408 & $5.4 \%$ & 7520 \\
\hline $\mathrm{RU}$ & 11 & $0.3 \%$ & 18 & $0.4 \%$ & 29 & $0.7 \%$ & 4286 \\
\hline SU & 126 & $0.9 \%$ & 20 & $0.1 \%$ & 146 & $1.0 \%$ & 14005 \\
\hline TUT & 93 & $4.5 \%$ & 26 & $1.3 \%$ & 119 & $5.8 \%$ & 2051 \\
\hline UCT & 40 & $0.3 \%$ & 4 & $0.0 \%$ & 44 & $0.3 \%$ & 14533 \\
\hline UFH & 220 & $14.7 \%$ & 160 & $10.7 \%$ & 380 & $25.4 \%$ & 1496 \\
\hline UFS & 115 & $1.9 \%$ & 36 & $0.6 \%$ & 151 & $2.5 \%$ & 6105 \\
\hline UJ & 224 & $4.3 \%$ & 18 & $0.3 \%$ & 242 & $4.6 \%$ & 5256 \\
\hline UKZN & 269 & $1.9 \%$ & 167 & $1.2 \%$ & 436 & $3.0 \%$ & 14449 \\
\hline UL & 151 & $7.7 \%$ & 68 & $3.5 \%$ & 219 & $11.2 \%$ & 1960 \\
\hline UNISA & 546 & $6.9 \%$ & 44 & $0.6 \%$ & 590 & $7.5 \%$ & 7863 \\
\hline UNIVEN & 164 & $14.9 \%$ & 74 & $6.7 \%$ & 238 & $21.7 \%$ & 1097 \\
\hline UP & 108 & $0.7 \%$ & 74 & $0.5 \%$ & 182 & $1.2 \%$ & 15348 \\
\hline UWC & 50 & $1.3 \%$ & 25 & $0.7 \%$ & 75 & $2.0 \%$ & 3801 \\
\hline UZ & 33 & $3.7 \%$ & 22 & $2.4 \%$ & 55 & $6.1 \%$ & 900 \\
\hline VUT & 42 & $7.3 \%$ & 12 & $2.1 \%$ & 54 & $9.4 \%$ & 573 \\
\hline WITS & 63 & $0.5 \%$ & 32 & $0.2 \%$ & 95 & $0.7 \%$ & 12929 \\
\hline WSU & 76 & $16.0 \%$ & 43 & $9.1 \%$ & 119 & $25.1 \%$ & 475 \\
\hline Total & 3015 & $2.5 \%$ & 1057 & $0.9 \%$ & 4072 & $3.4 \%$ & 119755 \\
\hline
\end{tabular}

Source: SA Knowledgebase, CREST

Note: The totals in this table are slightly higher than those in Table 2 because we used fractional counting of papers (which means that co-authored papers were assigned to each university) CPUT, Cape Peninsula University of Technology; CUT, Central University of Technology; DUT, Durban University of Technology; MUT, Mangosuthu University of Technology; NMMU, Nelson Mandela University; NWU, North West University; RU, Rhodes University; SU, Stellenbosch University; TUT, Tshwane University of Technology; UCT, University of Cape Town; UFH, University of Fort Hare; UFS, University of the Free State; UJ, University of Johannesburg; UKZN, University of KwaZulu-Natal; UL, University of Limpopo; UNISA, University of South Africa; UNIVEN, University of Venda; UP, University of Pretoria; UWC, University of the Western Cape; UZ, University of Zululand; VUT, Vaal University of Technology; WITS, University of the Witwatersrand; WSU, Walter Sisulu University 
One possible explanation can be found in the indexing of many of these journals in the Proquest IBSS list. Unlike journals indexed in the Web of Science, criteria for inclusion of journals on this list do not include citation metrics or any other bibliometric measures of quality control. It may well be that there is a disproportionately high representation of journals (the majority of which are in the social and management sciences) with unacceptable editorial and review practices that are indexed on this list.



Source: SA Knowledgebase, CREST

Figure 2: Distribution of predatory articles (number, percentage) classified as probably predatory (strong evidence) by subject category.

\section{Discussion}

Scholarly publishing in South African is strongly influenced by the DHET system of paying subsidies to universities for research publications. This, as we have argued elsewhere ${ }^{28}$, is the major driver behind the huge increase in publication output since 2005 and has become the major incentive for many academics to publish and publish as many articles as quickly as they can. If we assume that all the papers that we have identified as predatory received funding (at an average of around ZAR100 000 per full counted paper), an amount of ZAR100-R300 million (depending on whether we base our calculation on possible or probable) has been paid to universities for publications that have appeared in predatory journals, as classified by Beall. This should be cause for concern.

It is important to emphasise that it is not our view or intention to lay blame on individual academics who have published in predatory journals. There is enough evidence to indicate that many academics are quite unaware of these practices. Young and inexperienced scholars are often advised by senior academics to publish in such journals without knowing that this may compromise their academic career. It is equally important to point out that all of the 47 journals identified as predatory or possibly predatory in our database were at the time included in one of the three lists (the majority appears in the ProQuest IBSS list) recognised by the DHET for funding purposes. This means that academics (and their university research offices) were within their right to submit these papers for subsidy purposes and no 'rule' of the funding framework was violated. But this rather 'bureaucratic' position misses a main point of this article, namely that South African academics should not become complicit in predatory publishing on ethical grounds. Most of these journals do violate the basic rules of ethical publishing and research integrity and should therefore be avoided.

In a recent development, the US Federal Trade Commission has taken an interest in these 'predatory' publishers. More specifically, they have targeted the OMICS Group, a global conglomerate based in India and incorporated in Nevada that boasts more than 700 'leading-edge, peerreviewed' open access journals. All the evidence provided by Beall on OMICS makes it very clear that it is in fact a predatory publisher. As reported, 'in a historic first for the FTC, the agency is suing the company, alleging that it misrepresented the legitimacy of its publications, deceived researchers, and obfuscated sizeable publication fees'29.

The results of our study have consequences at the systemic, institutional and individual levels.
At the systemic level, national departments and agencies such as the DHET, Council on Higher Education and the National Research Foundation will have to take actions to ensure that predatory publishing does not become the norm at South African universities - especially in the human sciences - and compromise the quality of scientific and scholarly publishing in the country.

Arguably the main responsibility lies with the DHET who will have to take a stand on whether it will in the future fund papers that have appeared in journals that have been unequivocally identified to meet all or most of the criteria of a predatory journal. Their response to the case of the Mediterranean Journal of the Social Sciences suggests that they would decide not to do so. In order to discourage the practice of publishing in predatory journals and in so doing bringing the South African higher education system into disrepute, we believe that the DHET should - as a matter of urgency - revisit the lists that are currently approved for subsidy purposes (most notably the IBSS) and even consider placing a moratorium on the continued accreditation of those journals that are suspected of being predatory.

But it is also an issue that the Council on Higher Education, who has the systemic responsibility to assure quality in higher education, will have to take up and act upon. Perhaps the time has come to organise a national indaba at which all universities and stakeholders are represented to discuss this issue and measures to address the 'scourge' of predatory publishing and other questionable publication practices by South African academics. And, finally, it is very clear that the National Research Foundation will have to take an explicit position on this matter as it is not inconceivable that academics, and especially young academics, could in future apply for funding and ratings with CVs that include any number of papers in predatory journals and conference proceedings. In a recent communication, the National Research Foundation has in fact released a statement about its position on predatory publishing and has reserved the right to not consider applications that show evidence of predatory practices..$^{30}$

A number of South African universities have already taken steps to alert their staff to the dangers of predatory publishing, but a quick scan of university websites revealed that this applies more to the established research universities at which predatory publishing is less common. It is clear that the research offices at all South African universities need to proactively alert all their staff about the implications of predatory publishing. Equally importantly is the imperative to improve their validation procedures before papers are submitted for subsidy to the DHET. It is also important that academic librarians, who engage with academics on a daily basis, assume a responsibility in this regard.

Finally, at the individual scholar level, we argue that it is a specific responsibility for senior academics and specifically supervisors to be alert to the dangers of predatory publishing. In the same way that senior academics and supervisors inform and guide their younger colleagues and doctoral students about research ethics and the imperatives of conforming to good practice in research integrity, it now becomes an additional responsibility to guide young academics in their publication strategies and choices. Young scholars should, for example, be encouraged to consult the very useful Think Check Submit tool that can assist them in deciding where to publish.

It is well documented ${ }^{14,15}$ that younger scholars, and very often doctoral graduates, are targeted by these predatory publishers. Unless they are properly informed and guided in their publication strategies, young scholars could find themselves building a CV that is increasingly based on publishing in questionable journals. There is even the danger that, if journal articles submitted as part of a doctoral thesis (so-called 'PhD by papers') are in predatory journals, the quality assurance process of the doctorate may be compromised.

In the final analysis, it is clear that predatory publishing poses a serious challenge to science in South Africa. If it continues to increase at the rate of growth seen in the past 5 years, predatory publishing may well become accepted practice in some disciplines and at some universities. Not only will it affect the very fabric of the science system (our confidence in the 
peer-review system), but it will also undermine the trust and confidence of the general public in science and its products.

\section{Acknowledgements}

We thank all the technical staff at CREST, in particular, Lynn Lorenzen, Annemarie Visagie, Herman Redelinghuys and Johann Spies, for their roles in the production of the data. We also thank Nico Cloete, Gansen Pillay and Johan Muller for their valuable comments on earlier drafts of the paper and the anonymous reviewers for their detailed and useful comments on a previous version of the paper.

\section{Authors' contributions}

J.M. conceptualised the study on which the paper is based and wrote the main text of the paper. A.V. was responsible for data cleaning and generation of tables and charts for the paper.

\section{References}

1. De Jager P, Van der Spuy P, De Kock F. Do not feed the predators. Working paper. October 2016. https://dx.doi.org/10.13140/RG.2.2.20268.67203

2. Thomas A. African academics are being caught in the predatory journal trap. The Conversation. 2015 October 29. Available from: https://theconversation. com/african-academics-are-being-caught-in-the-predatory-journaltrap-48473

3. Bohannon J. Who's afraid of peer review? Science. 2013;342:60-65. https:// dx.doi.org/10.1126/science.342.6154.60

4. Bowman JD. Predatory publishing, questionable peer review, and fraudulent conferences. Am J Pharm Educ. 2014;78(10), Art. \#176, 6 pages. https:// dx.doi.org/10.5688/ajpe7810176

5. Djuric D. Penetrating the omerta of predatory publishing: The Romanian connection. Sci Eng Ethics. 2015;21:183-202. https://dx.doi.org/10.1007/ s11948-014-9521-4

6. Gasparyan AY, Yessirkepov M, Diyanova SN, Kitas GD. Publishing ethics and predatory practices: A dilemma for all stakeholders of science communication. J Korean Med Sci. 2015;30:1010-1016. https://dx.doi. org/10.3346/jkms.2015.30.8.1010

7. Jalalian M, Mahboobi H. Hijacked journals and predatory publishers: Is there a need to re-think how to assess the quality of academic research? Walailak J Sci Tech. 2014;11(5):389-394. https://dx.doi.org/10.14456/WJST.2014.16

8. Kozak MK, lefremova 0, Hartley J. Spamming in scholarly publishing: A case study. J Assn Inf Sci Tec. 2016;67:2009-2015. https://dx.doi.org/10.1002/ asi. 23521

9. Nelson N, Huffman J. Predatory journals in library databases: How much should we worry? Serials Libr. 2015;69(2):169-192. https://dx.doi.org/10.1 080/0361526X.2015.1080782

10. Shen C, Biörk B-C. 'Predatory' open access: A longitudinal study of article volumes and market characteristics. BMC Med. 2015;13, Art. \#230, 15 pages. https://dx.doi.org/10.1186/s12916-015-0469-2

11. Sipka P. Legitimacy of citations in predatory publishing: The case of proliferation of papers by Serbian authors in two Bosnian WoS-indexed journals. CEES Occasional Paper Series No. 2012-12-2. Available from: http://www.ceon.rs/ops/12122.pdf
12. Svab I, Makivic I. Predators and hijackers in academic publishing. Eur J Gen Pract. 2015;21(2):95-96. https://dx.doi.org/10.3109/13814788.2015.1037 270

13. Tin L, Ivana B, Biljana B, Ljubica IB, Dragan M, Dusan S. Predatory and fake scientific journals/publishers - A global outbreak with rising trend: A review. Geogr Pannon. 2014;18(3):69-81.

14. Xia J, Harmon JL, Connolly KG, Donnelly RM, Anderson MR, Howard HA. Who publishes in 'predatory' journals? J Assoc Inf Sci Technol. 2015;66(7):14061417. http://dx.doi.org/10.1002/asi.23265

15. Xia J. Predatory journals and their article publishing charges. Learn Publ. 2015;28(1):69-74. https://dx.doi.org/10.1087/20150111

16. Truth F. Pay big to publish fast: Academic journal rackets. J Crit Educ Pol Stud. 2012;10(2):54-105.

17. Bartholomew RE. Science for sale: The rise of predatory journals. JR Soc Med 2014;107(10):384-385. https://dx.doi.org/10.1177/0141076814548526

18. Moher D, Srivastava A. You are invited to submit... BMC Med. 2015;13, Art. \#180, 4 pages. https://dx.doi.org/10.1186/s12916-015-0423-3

19. Weller AC. Editorial peer review: Its strengths and weaknesses. Asis\&T Monograph Series. Medford, NJ: Information Today; 2001.

20. Lin S. Why serious academic fraud occurs in China. Learn Publ. 2013;26(1):24-27. https://dx.doi.org/10.1087/20130105

21. Beall J. What I learned from predatory publishers. Biochem Med (Zagreb). 2017;27(2):273-279. https://doi.org/10.11613/BM.2017.029.

22. Beall J. Predatory publishers are corrupting open access. Nature. 2012;489:179. https://dx.doi.org/10.1038/489179a

23. Coyle K. Predatory publishers: Peer to peer review. Library Journal. 2013 April 04. Available from: http://li.libraryjournal.com/2013/04/opinion/peer-to-peerreview/predatory-publishers-peer-to-peer-review

24. Crawford W. Ethics and access 1: The sad case of Jeffrey Beall. Cites \& Insights. 2014;14(4):1-14.

25. Beall's list of predatory journals and publishers [homepage on the Internet]. No date [updated 2016 Dec 31; cited 2017 Jun 25]. Available from: http:// beallslist.weebly.com/

26. Beall's response regarding inclusion of the International Journal of Electrochemical Science as a predatory journal [homepage on the Internet]. c2012 [cited 2017 Jan 10]. Accessed at: http://0-admin-apps. webofknowledge.com.skyline.ucdenver.edu/JCR/static_html/notices/ notices.htm [this link is now defunct]

27. Beall J. The continuing story of the African Journal of Business Management [blog]. c2012 [cited 2017 Jan 10]. Accessed at: https://scholarlyoa. com/2012/01/15/the-continuing-story-of-the-african-journal-of-businessmanagement/ [this link is now defunct]

28. Mouton J, Gevers W. Introduction. In: Academy of Science of South Africa (ASSAf), editor. The state of science in South Africa. Pretoria: ASSAf; 2008. p. 39-67.

29. Molteni M. The FTC is cracking down on predatory science journals [homepage on the Internet]. c2016 [cited 2017 Jun 25]. Available from: https://www.wired.com/2016/09/ftc-cracking-predatory-science-journals/

30. South African National Research Foundation (NRF). NRF Statement on predatory journals \& deceptive publishers [homepage on the Internet]. 2017 March 22 [cited 2017 Jun 25]. Available from: http://www.nrf.ac.za/mediaroom/news/nrf-statement-predatory-journals-deceptive-publishers 